Article

\title{
Revisiting the Intermediate Sediment Repository Concept Applied to the Provenance of Zircon
}

\author{
Manuel Francisco Pereira * and Cristina Gama \\ Departamento de Geociências, Instituto de Ciências da Terra, ECT, Universidade de Évora, \\ Apt. 94, 7002-554 Evora, Portugal; cgama@uevora.pt \\ * Correspondence: mpereira@uevora.pt
}

Citation: Pereira, M.F.; Gama, C. Revisiting the Intermediate Sediment Repository Concept Applied to the Provenance of Zircon. Minerals 2021, 11, 233. https://doi.org/10.3390/ $\min 11030233$

Academic Editor: Antonio Simonetti

Received: 16 November 2020

Accepted: 22 February 2021

Published: 25 February 2021

Publisher's Note: MDPI stays neutral with regard to jurisdictional claims in published maps and institutional affiliations.

Copyright: (c) 2021 by the authors. Licensee MDPI, Basel, Switzerland. This article is an open access article distributed under the terms and conditions of the Creative Commons Attribution (CC BY) license (https:// creativecommons.org/licenses/by/ $4.0 /)$.

\begin{abstract}
This paper revisits the intermediate sediment repository (ISR) concept applied to provenance, using a comparison of the detrital zircon population of Holocene beach sand from the southwest Portuguese coast with populations from their potential source rocks. The $\mathrm{U}-\mathrm{Pb}$ age of detrital zircon grains in siliciclastic rocks allows for the interpretation of provenance by matching them with the crystallization ages of igneous source (protosource) rocks in which this mineral originally crystallized or which was subsequently recycled from it, acting as ISRs. The comparative analysis of the Precambrian, Paleozoic, and Cretaceous ages using recent statistical tools (e.g., kernel density estimator (KDE), cumulative age distribution (CAD), and multidimensional scaling (MDS)) suggests that the zircon age groups of Carboniferous, Triassic, and Pliocene-Pleistocene ISRs are reproduced faithfully in Holocene sand. Furthermore, the recycling of a protosource (Cretaceous syenite) in a sedimentary system dominated by ISRs is evaluated. It is argued that the ISR concept, which is not always taken into account, is required for a better understanding of the inherent complexity of local provenance and to differentiate sediment recycling from first- cycle erosion of an igneous rock.
\end{abstract}

Keywords: zircon $\mathrm{U}-\mathrm{Pb}$ dating; provenance; sediment recycling; siliciclastic rocks; plutonic rocks; protosource

\section{Introduction \\ 1.1. Zircon}

Zircon crystallizes from magma that is saturated in zirconium, and it may undergo the dissolution and recrystallization associated with magmatic and metamorphic processes [1-3]. The composition of the magma and the temperature of crystallization affect the morphology of zircon, which may present different external forms [1]. Zircon formed by distinct processes shows a wide variety of internal patterns which can only be identified efficiently by using cathodoluminescence images [2,3]. Magmatic zircon may have a structure corresponding to a single crystallization event, or it may be composite, representing more than one crystallization event as indicated by the core and rim patterns [4]. In the latter case, the core may represent an early stage of crystallization or older zircon that derived from the host rocks [5,6]. Zircon that grows during metamorphism tends to form growths surrounding the older (inherited) grains or appear to be non-composite grains, representing a unique growth event [4].

Zircon is common in most sedimentary systems associated with the deposition of siliciclastic rocks because it is extremely resilient in the face of erosion, which makes it invaluable for provenance studies. At present, the $\mathrm{U}-\mathrm{Pb}$ age of detrital zircon may be determined with precision and accuracy by using a laser ablation inductively coupled plasma mass spectrometer (LA-ICP-MS), sensitive high-resolution ion microprobe (SHRIMP), and thermal ionization mass spectrometry (TIMS) $[4,7,8]$. These have all been used as a proxy for the age of the source (magmatic, metamorphic, or sedimentary) rock from which it was sourced [9]. 
Sediment may be derived from different sources located either close to or far from the sedimentary basin (Figure 1), and its detrital zircon content depends on the dispersal path of the sediment from the inferred provenance area to the sedimentary basin [7,10-12].

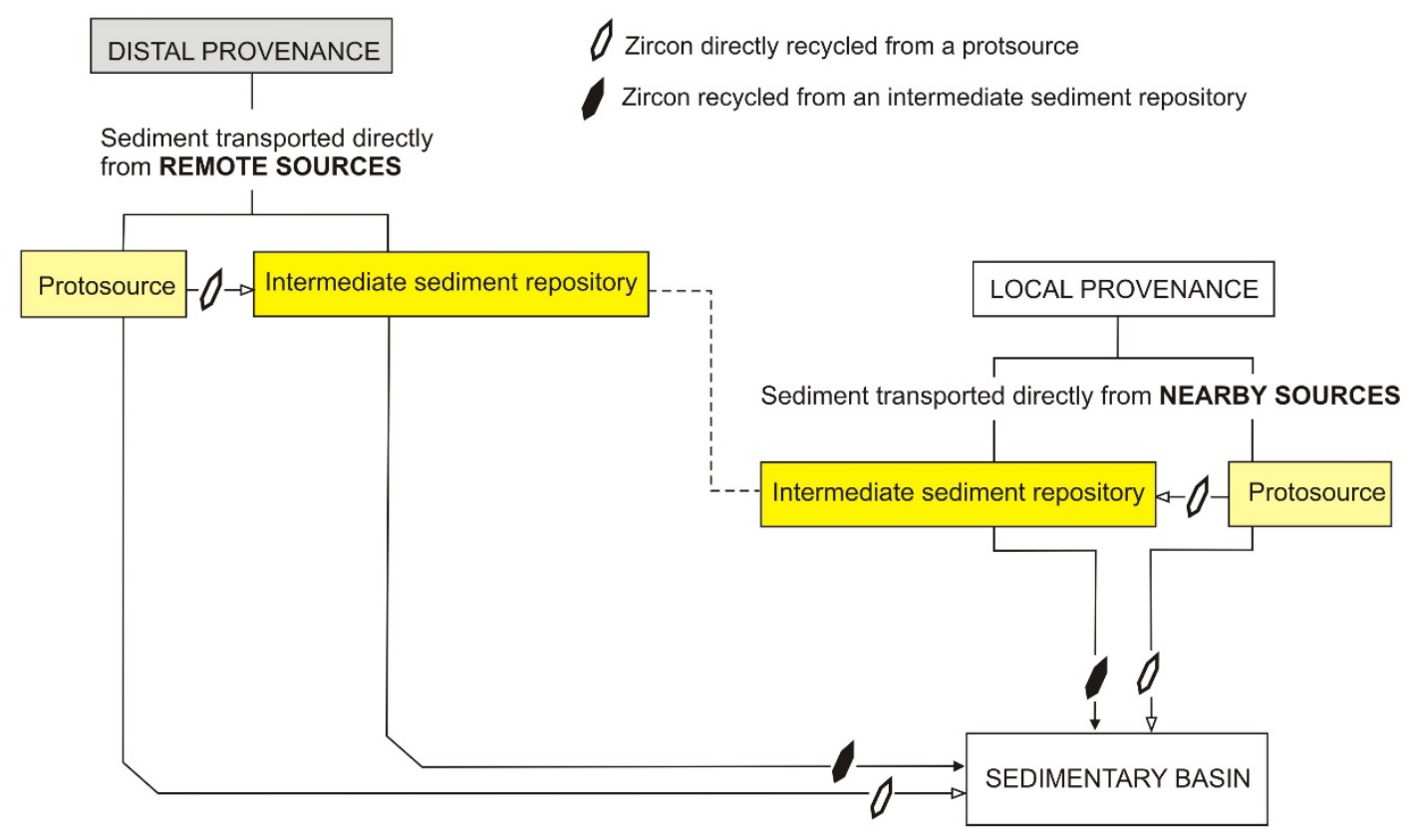

Figure 1. Schematic diagram illustrating the interplay between distal and local provenance, remote and nearby sources, protosources, and intermediate sediment repositories (ISRs).

Sedimentary rocks may contain zircon grains derived from older sources that are not exposed in the provenance areas draining to the basin; thus, they pass through an intermediate sediment repository (ISR) before reaching the sink $[9,13]$. Comparing the detrital zircon population of siliciclastic rocks with the crystallization ages of potential protosources (i.e., the igneous or metamorphic rock [14-17] in which zircon crystallizes) or an ISR that includes grains recycled directly from protosources (first-cycle erosion) and an older ISR is crucial in provenance studies $[9,13]$. Nevertheless, recycling from older sedimentary deposits may be more significant than first-cycle derivation from a protosource. Overlooking the possibility that detrital zircon age clusters may have resulted from the multi-cycle recycling of older magmatic, sedimentary, or metamorphic rocks may lead to the misinterpretation of their provenance [8].

\subsection{The Intermediate Sediment Repository (ISR) Concept}

One of the most relevant concepts for studying the source rocks from which sediments are derived is that of the protosource, developed by Pell et al. [17] for fingerprinting the provenance regions of modern Australian dune sands using $\mathrm{U}-\mathrm{Pb}$ dating of detrital zircon grains. These authors used the term protosource (Figure 1) to describe the parent igneous rocks in which a zircon grain crystallizes. In accordance with their definition, they also considered the metamorphosed derivatives of those igneous parent rocks to be protosources but excluded metasedimentary deposits derived from the recycling of many different areas.

A reference study by Sircombe [13] on the provenance of Cenozoic siliciclastic deposits from eastern Australia made emphasis on the concept of the intermediate sediment repository (ISR), which is also relevant. This author studied the U-Pb detrital zircon populations of Holocene sands sampled along the coastline and compared them with those from potential nearby and remote sources of Precambrian to Tertiary ages.

Sircombe's results [13] highlighted the pervasive occurrence of a significant age group of Precambrian (mostly Neoproterozoic) detrital zircon in the modern beach sands of 
eastern Australia. This finding was intriguing because local sources of this age were not previously known near the sampled sites, with the closest known coastal exposure of Precambrian rocks occurring about $1000 \mathrm{~km}$ away in the Adelaide Orogen.

In search of the potential sources of the Neoproterozoic detrital zircon age group found in the Holocene sands, the author decided to study Triassic (Sydney Basin) and Tertiary (Murray Basin) siliciclastic rocks by performing tests to find out whether Neoproterozoic grains had passed through ISRs before reaching the modern beach. This followed a similar study previously conducted on Precambrian detrital zircon found in Paleozoic sedimentary rocks (in the Lachlan Fold Belt [18]) and Quaternary dune sands (in the Mallee dune field, which overlaps the Tertiary Murray Basin [17]) of eastern Australia. Sircombe [13] recognized that the Neoproterozoic detrital zircon age group was almost ubiquitous with Triassic and Tertiary siliciclastic rocks and Holocene beach sands. Thus, it is plausible that the Sidney and Murray basins acted as ISRs, and that the Precambrian zircon found in Holocene deposits was recycled from the older siliciclastic rocks. This previous research has shown that the detrital zircon input from ISRs may be superimposed on the fingerprint of local sources $[7,19]$ and may also mimic a protosource that is not presently exposed in the proximity of the sedimentary basin (Figure 1).

In this paper, we intend to revisit the ISR concept by performing a comparative study of zircon age populations from potential nearby sources of a modern sedimentary basin, based on a statistical approach using a kernel density estimator (KDE), the Kolmogorov-Smirnov $(\mathrm{K}-\mathrm{S})$ test to produce cumulative age distribution (CAD) curves [20-22], and multidimensional scaling (MDS) graphs [23-25], which have been increasingly used in provenance studies. We aim to provide a contribution toward the discussion regarding the interplay between distinct ISRs (Carboniferous, Triassic, and Pliocene-Pleistocene siliciclastic rocks) and an igneous protosource (Cretaceous) that provides zircon grains to the Holocene beaches of the southwest Portuguese coast (Figure 2A).

\section{Study Area}

\subsection{Geomorphology and Geology}

In the Sines-Santiago do Cacém region (southwest Portuguese coast), the Holocene beach is bound landward by Holocene dunes and sea cliffs. The Holocene beach north of Cape Sines is characterized by mean grain size variations that present progressive longshore coarsening southward, going from medium (Areias Brancas beach) to very coarse (Ribeira de Moinhos beach) grain sizes [26]. South of Cape Sines, fine to medium sand is found at the beach in São Torpes (Figure 1) [27].

The sea cliffs mostly comprise the Pliocene-Pleistocene sandstones and conglomerates of the Alvalade Basin (north of Cape Sines), the Cretaceous plutonic rock exposures of Cape Sines, and the Carboniferous metasedimentary rocks of the South Portuguese Zone (south of Cape Sines) [16,28-30] (Figure 2C) that represent the uplifted pre-Mesozoic basement of southwest Iberia.

The coastal plain through which the main streams flow toward the sea cliffs is interrupted by a topographic relief $20 \mathrm{~km}$ inland, which is controlled by NNE-SSW-oriented active faults. These streams, which carry sediment to beaches, have provenance areas located west of the Santiago do Cacém topographic relief with a height of 260-291 m (Figure 2B). The stream catchment zones are underlain by Lower Jurassic limestones and Upper Triassic sandstones and conglomerates of the Alentejo Basin, as well as the Carboniferous siliciclastic rocks of the South Portuguese Zone [31] (Figure 2C). 


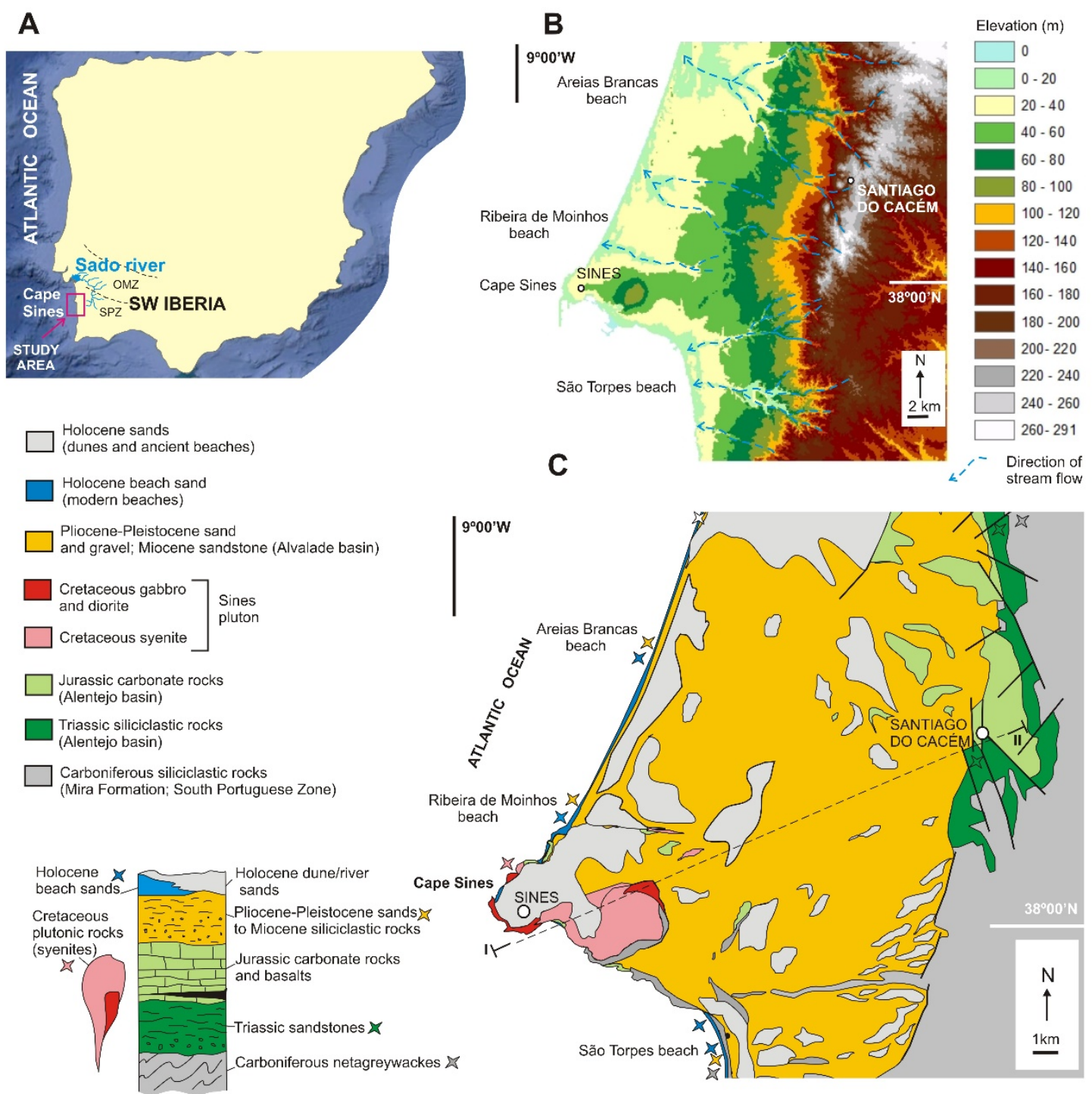

Figure 2. (A) Inset with the location of SW Iberia in a Google Earth Pro image of the Iberian Peninsula (western Europe) showing two tectonic units of the Variscan orogenic belt. OMZ = Ossa-Morena Zone, and SPZ = South Portuguese Zone, which includes the drainage system of the Sado River. (B) Digital elevation model based on high-resolution topographic data of the Shuttle Radar Topography Mission (SRTM-NASA), showing the relief and the drainage system (blue dashed lines) of the study area of Sines-Santiago do Cacém. (C) Simplified geological map and stratigraphy (the stars are units with $\mathrm{U}-\mathrm{Pb}$ zircon data presented in Figures 3-5) of the Sines-Santiago do Cacém region, showing the Holocene sand deposits, the Pliocene-Pleistocene Alvalade Basin, the Triassic Alentejo Basin, and the Carboniferous South Portuguese Zone rocks (adapted from [31,32]). I-II = cross-section of Figure 6.

\subsection{Potential Sediment Sources}

This study focuses on testing for the existence of potential nearby sources for Holocene beach sands. In the Sines-Santiago do Cacém region, the oldest exposed rocks belong to an Upper Devonian volcano-sedimentary complex, and a Lower Carboniferous sequence of greywackes and shales belong to the South Portuguese Zone (including the SerpukhovianBashkirian Mira Formation). These Carboniferous metasedimentary rocks (turbidites), which were derived from denudation of the Late Paleozoic Variscan orogenic belt with massive Lower Carboniferous magmatism [33], are exposed on the sea cliff south of Cape Sines, along the course of the streams, and in the topographic relief of Santiago do Cacém (Figure 2C). At Santiago do Cacém, an angular unconformity between the Carboniferous siliciclastic rocks of the Mira Formation and the overlying sandstones and conglomerates 
of the Triassic Alentejo Basin may be recognized [34]. Triassic siliciclastic rocks, which result from the erosion of the Variscan basement rocks [34,35], show a conformable upper contact with overlying Lower Jurassic limestones and interbedded basalts (Figure 2C), which were formed during the early stages of opening of the North Atlantic Ocean circa 197-196 Ma [36].

Cape Sines mostly consists of an Upper Cretaceous pluton (circa 77-74 Ma [16,37]) composed of syenite, gabbro, diorite, and mafic breccias, surrounded by the host MiddleUpper Jurassic limestones of the Alentejo Basin. Cretaceous plutonism occurred in a postrift setting that lasted throughout the rotation of the Iberia microplate and the initiation of Alpine compression [37]. The Sines pluton is submerged to the west and covered by Cenozoic deposits that occur inland to the east (Figure 2C).

Close to Cape Sines, the sea cliff also includes the Middle-Upper Jurassic limestones of the Alentejo Basin and the Pliocene-Pleistocene siliciclastic deposits of the Alvalade Basin. Cenozoic sedimentary deposits unconformably overlie Carboniferous turbidites, Jurassic limestones, and Cretaceous plutonic rocks [31]. Pliocene-Pleistocene deposition is associated with transport along main rivers, whose mouths are located on the Atlantic coast [38], controlled by Alpine faults [28]. The Cenozoic sedimentary rocks of the Alvalade Basin also unconformably overlie the Paleozoic sedimentary, metamorphic, and igneous rocks of the Ossa Morena Zone that occur inland to the east [28]. This Late Paleozoic tectonic unit of the Variscan orogenic belt is made of Cambrian to Carboniferous sedimentary rocks, mostly derived from the recycling of Ediacaran sedimentary and magmatic arc rocks, as well as Cambrian-Lower Ordovician magmatic rocks [30]. These potential remote sources are exposed in the catchment zones of where the Sado River drains into the Atlantic Ocean (Sado Ebb-tidal delta), located $65 \mathrm{~km}$ north of Cape Sines.

\section{Statistical Analysis of U-Pb Zircon Ages}

The quantitative analysis presented in this study was based on a compilation of detrital zircon $\mathrm{U}-\mathrm{Pb}$ ages from Holocene beach sands [16] and their potential metasedimentary and sedimentary sources $[16,28,29,33,34,39-41]$, as well as igneous zircon ages from Sines plutons $[16,30]$. LA-ICP-MS measurements, $90-110 \%$ concordant ${ }^{206} \mathrm{~Pb}^{238} \mathrm{U}$ ages for grains younger than $1.0 \mathrm{Ga}$, and ${ }^{207} \mathrm{~Pb}-{ }^{206} \mathrm{~Pb}$ ages for older grains [41] were used to compare the distinct populations of zircon $\mathrm{U}-\mathrm{Pb}$ ages obtained. The geochronological methods are described in $[16,28,29,34,39,40]$. Table 1 presents a summary of the zircon $\mathrm{U}-\mathrm{Pb}$ ages obtained.

\subsection{Kernel Density Estimator}

Figure 3 shows the KDE, graphed using IsoplotR [24]. KDE is a method for visualizing detrital age distributions, which involves obtaining the sum of a set of Gaussian distributions, but in contrast to the probability density plot, it does not explicitly take into account analytical uncertainties [42]. KDE graphs are shown for all detrital zircon ages (Figure 3A) and the Precambrian age group (Figure 3B) of Carboniferous metasedimentary rocks, Triassic and Pliocene-Pleistocene siliciclastic rocks, and Holocene beach sand.

Figure $3 \mathrm{~A}$ shows that the age population of the Carboniferous and Triassic samples appeared to be quite similar, predominantly presenting Precambrian grains followed by Paleozoic grains. The detrital zircon age populations of Pliocene-Pleistocene and Holocene siliciclastic deposits showed differences in the percentages of the youngest age groups (Table 1). The Pliocene-Pleistocene siliciclastic rocks and Holocene sand were distinct from the Carboniferous and Triassic bedrock because they contained Cretaceous zircon grains and a greater abundance of Paleozoic ages compared with the Precambrian age group. 

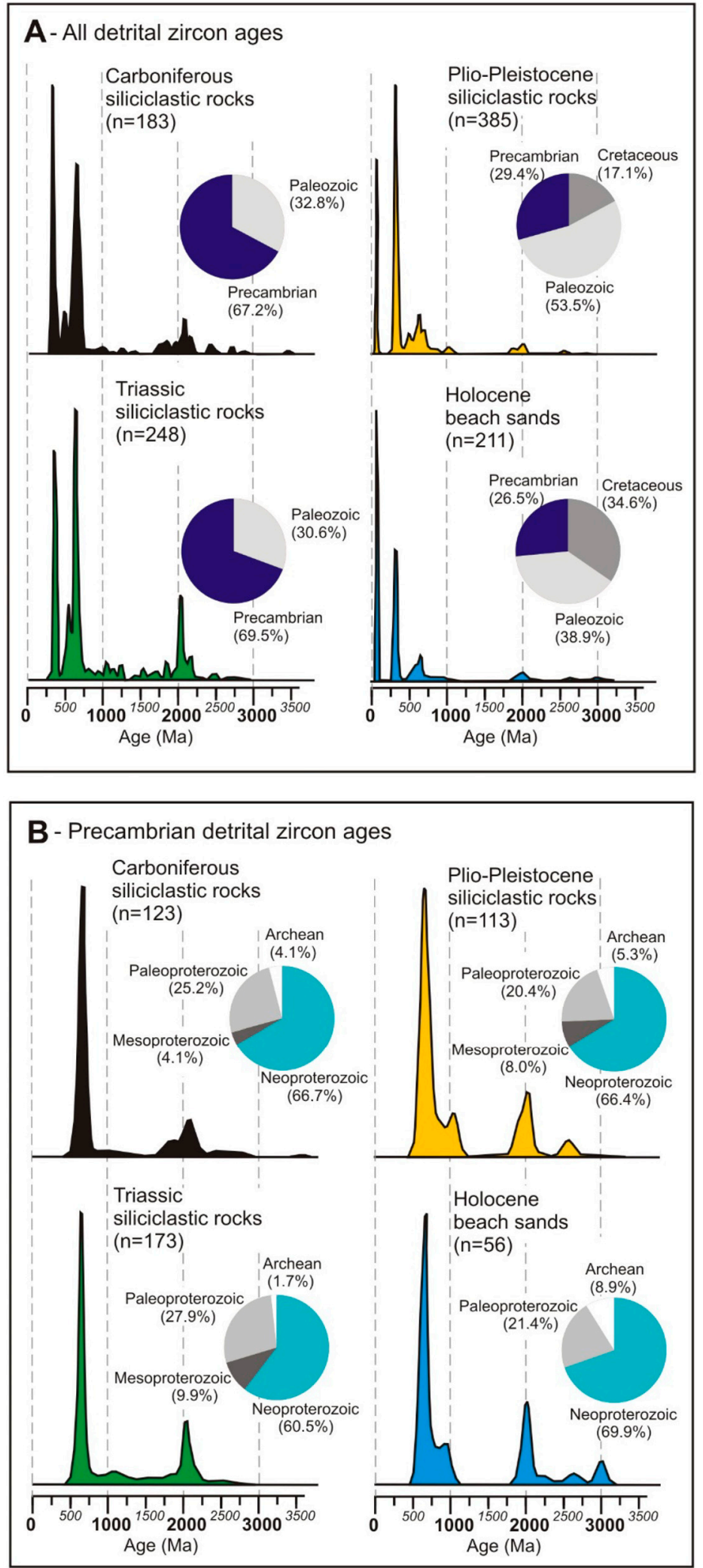

Figure 3. Kernel density estimation (KDE) plots and pie charts with $\mathrm{U}-\mathrm{Pb}$ detrital zircon ages of the Carboniferous (Mira Formation, South Portuguese Zone), Triassic (Silves Group, Alentejo Basin), Pliocene-Pleistocene (Alvalade Basin) siliciclastic rocks, and Holocene beach sands from the Sines region. (A) All detrital zircon ages. (B) Precambrian detrital zircon ages (U-Pb data compiled from $[16,28,29,34,39,40])$. 
Table 1. Ranges of detrital zircon age groups of the Carboniferous to Pliocene-Pleistocene siliciclastic rocks, the Cretaceous plutonic rocks, and the Holocene beach sand ( $\mathrm{U}-\mathrm{Pb}$ data from $[16,28,29,34,39,40])$. Age intervals are based on laser ablation inductively coupled plasma mass spectrometer (LA-ICP-MS) results with $90-110 \%$ concordance. The attribution of U-Pb ages to chronostratigraphic units followed the International Chronostratigraphic Chart v2020/01. Values are expressed in Ma.

\begin{tabular}{|c|c|c|c|c|c|}
\hline & $\begin{array}{l}\text { Carboniferous } \\
\text { Metagreywacke }\end{array}$ & $\begin{array}{c}\text { Triassic } \\
\text { Sandstone }\end{array}$ & $\begin{array}{l}\text { Pliocene- } \\
\text { Pleistocene } \\
\text { Sand }\end{array}$ & $\begin{array}{l}\text { Holocene } \\
\text { Sand }\end{array}$ & $\begin{array}{c}\text { Cretaceous } \\
\text { Syenite }\end{array}$ \\
\hline Cretaceous & - & - & $\begin{array}{c}72-95 \\
113\end{array}$ & 73-95 & $74-87$ \\
\hline Paleozoic & $\begin{array}{c}312-402 \\
426 \\
454 \\
465-538\end{array}$ & $\begin{array}{c}296 \\
312 \\
327-405 \\
463-541\end{array}$ & $\begin{array}{l}277-293 \\
297-401 \\
413-457 \\
477-539\end{array}$ & $\begin{array}{l}301-376 \\
476-531\end{array}$ & - \\
\hline Neoproterozoic & $548-992$ & $547-964$ & $542-973$ & 553-979 & 623 \\
\hline Mesoproterozoic & 1011-1407 & $1037-1538$ & $\begin{array}{c}1010-1085 \\
1546\end{array}$ & & - \\
\hline Paleoproterozoic & $1716-2450$ & $1617-2475$ & $1813-2191$ & $1922-2274$ & - \\
\hline Archean & $\begin{array}{c}2518-2863 \\
3461\end{array}$ & 2504-2755 & 2504-2874 & $2664-3024$ & - \\
\hline
\end{tabular}

Comparative analysis of the Precambrian group of detrital zircon grains indicated that there were no substantial differences between the different analyzed rocks, apart from their Archean ages. The dominant age group was the Neoproterozoic age, followed by the Paleoproterozoic age. The Mesoproterozoic and Archean ages were the least represented, while Mesoproterozoic grains were absent in Holocene beach sand (Figure 3B).

\subsection{K-S Test and Cumulative Age Distribution}

A K-S test was conducted to compare the zircon ages of different populations and the respective cumulative age distribution (CAD) curves produced. The representation of each zircon age population or age group was assured because over 20 measurements were included of whatever number of grains was analyzed. Regarding the maximum vertical $\left(D_{\max }\right)$ difference between the CAD curves, the greater the distance, the greater the significance of the difference between the zircon age populations or age groups, indicating that the two samples were not derived from the same source $[20,21,43]$.

In this study, an Excel spreadsheet published on the University of Arizona Geochronological Center website (https:/ / sites.google.com/a/laserchron.org/laserchron/) was used to perform the K-S test (Table 2), and IsoplotR [24] was used to graph the CAD curves. The CAD curves allowed for the comparison of the distributions for distinct groups of the zircon ages of Carboniferous metasedimentary rocks, Triassic and Pliocene-Pleistocene siliciclastic rocks, Cretaceous plutonic rocks, and Holocene beach sand. In Figure 4A, with regard to the distance between the CAD curves, the Carboniferous and Triassic samples are very close to each other and more distant from the Pliocene-Pleistocene and Holocene deposits. The cumulative curve of the igneous zircon from Cretaceous syenite diverges from the other four CAD curves because it included only the youngest ages. Figure $4 \mathrm{~B}$ shows how the CAD curves for the Precambrian detrital zircon ages of all the above siliciclastic samples overlap, with some minor differences. 
Table 2. Results of the Kolmogorov-Smirnov (K-S) test of the detrital zircon distribution ages of the Carboniferous, Triassic, and Pliocene-Pleistocene siliciclastic rocks, as well as Holocene beach sand (U-Pb data from [16,28,29,34,39,40]). Age intervals are based on LA-ICP-MS results with 90-110\% concordance. DZ = Detrital zircon. Age groups: PR = Precambrian zircon, PZ = Paleozoic zircon, and PZ + PR = combination of Paleozoic and Precambrian zircon. ISR = intermediate sediment repository. The probability of the observed D-value being unrelated to age differences between the two populations or age groups is given by a $p$-value corresponding to a confidence interval of $95 \%$ [21], with high D-values and low $p$-values indicating that the observed difference between the two populations or age groups may be explained by distinct sources [43]. Numbers in bold with a $p$-value $>0.05$ indicate zircon populations or age groups that are not significantly different; D-values using error in the CDF are indicated by underlined values.

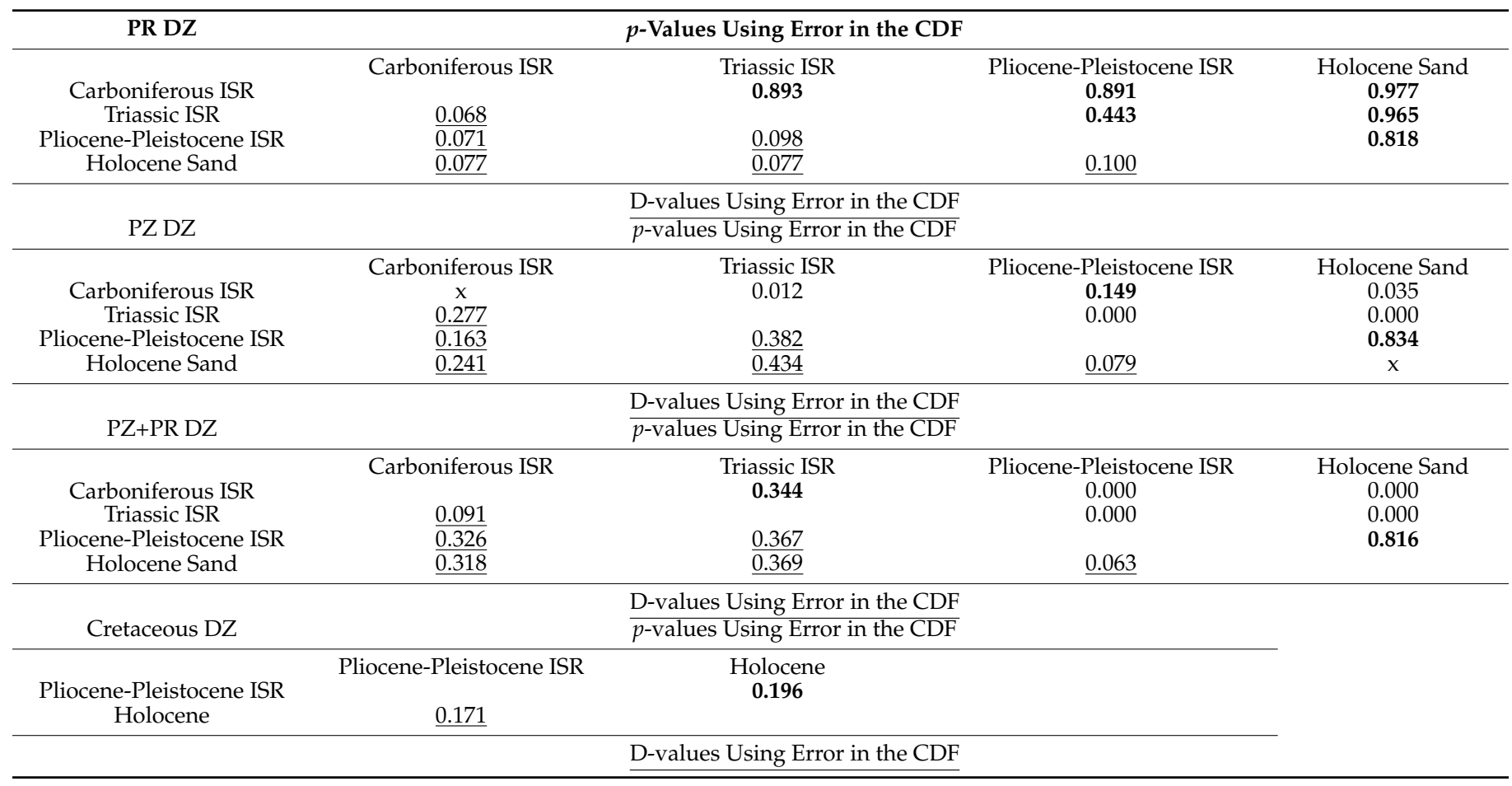

A - All zircon ages

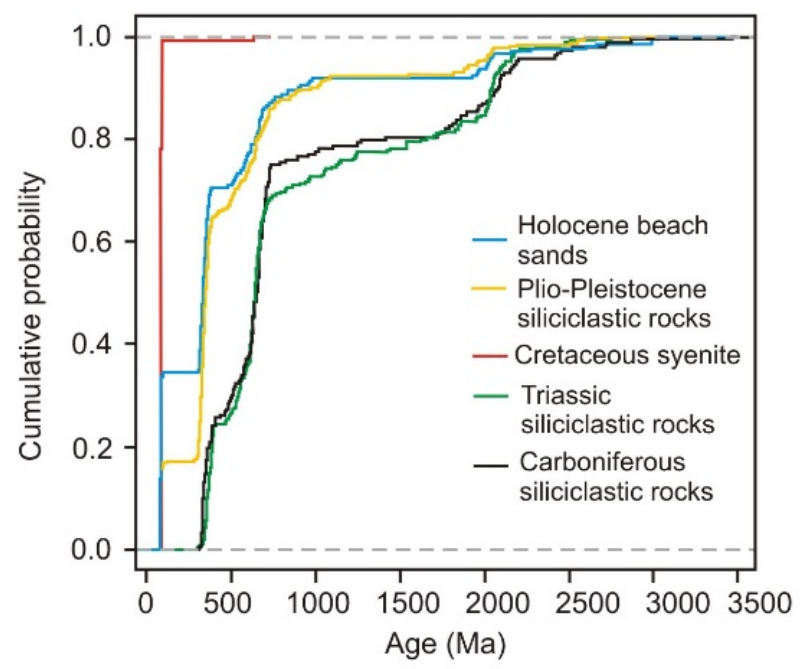

B - Precambrian detrital zircon ages

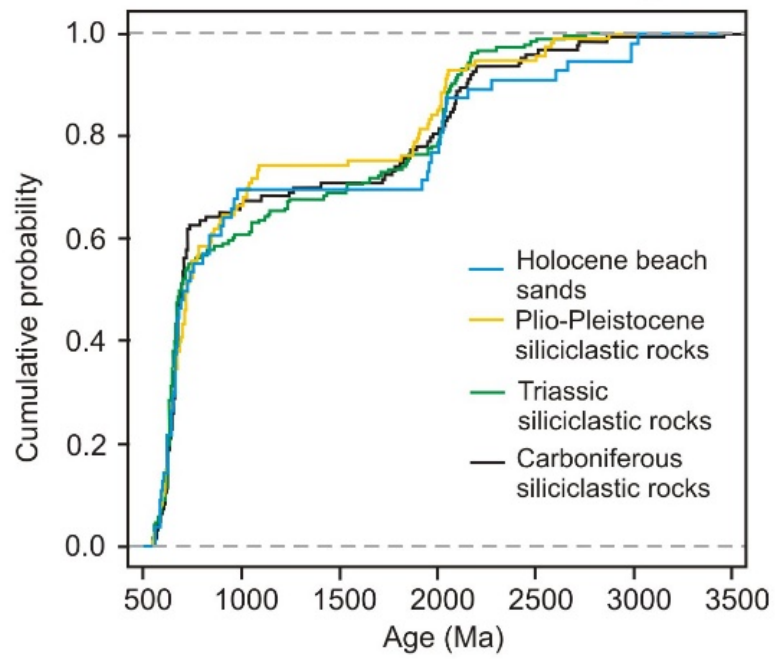

Figure 4. Cumulative age distributions of the zircon $\mathrm{U}-\mathrm{Pb}$ ages from the Carboniferous (Mira Formation, South Portuguese Zone), Triassic (Silves Group, Alentejo Basin), and Pliocene-Pleistocene (Alvalade Basin) siliciclastic rocks, the Cretaceous plutonic rocks (Sines pluton), and Holocene beach sands from the Sines region. (A) All (detrital and magmatic) zircon ages. (B) Precambrian detrital zircon ages (U-Pb data compiled from $[16,28,29,34,39,40])$. 


\subsection{Multidimensional Scaling}

The multidimensional scaling (MDS) technique transformed a matrix of pairwise dissimilarities among the detrital zircon age populations of several samples into Cartesian coordinates in a two-dimensional space [25]. MDS graphs, performed using IsoplotR [24], were extremely intuitive for visualizing the relationship between the detrital age distributions, where greater distances between samples represented a greater degree of dissimilarity between them.

This statistical tool provided useful means for verifying whether the zircon age populations found in the older siliciclastic rocks were reproduced faithfully in younger ones as result of sediment recycling. The MDS diagram for all detrital zircon ages (Figure 5A) shows that (1) the detrital zircon population of Carboniferous siliciclastic rocks was very similar to that of the Triassic siliciclastic rocks; (2) there was similarity between the PliocenePleistocene and Holocene detrital zircon populations; and (3) there was a certain degree of dissimilarity between the above pairs. Thus, Carboniferous siliciclastic rocks may be regarded as a source for Triassic siliciclastic rocks, whereas the potential source of Holocene beach sand seems to be Pliocene-Pleistocene siliciclastic rocks.

The MDS diagram for Precambrian detrital zircon ages (Figure 5B) shows proximity between the detrital zircon age groups of the Carboniferous and Triassic siliciclastic rocks. These older sedimentary rocks were plotted close to Holocene beach sand. The PliocenePleistocene rocks being linked to Holocene sand shows a tenuous connection with Carboniferous siliciclastic rocks. The MDS graph for the Paleozoic detrital zircon ages (Figure 5C) suggests a stronger association between the Pliocene-Pleistocene and Carboniferous rocks.

In Figure 5D, Cretaceous syenites are located a considerable distance from the Carboniferous and Triassic siliciclastic rocks, and they are associated with Pliocene-Pleistocene and Holocene sedimentary deposits. As for the provenance of Pliocene-Pleistocene siliciclastic rocks and Holocene beach sand, the MDS diagram suggests significant derivation from the erosion of Cretaceous syenites and Carboniferous and Triassic siliciclastic rocks, which are statistically distinguishable. 

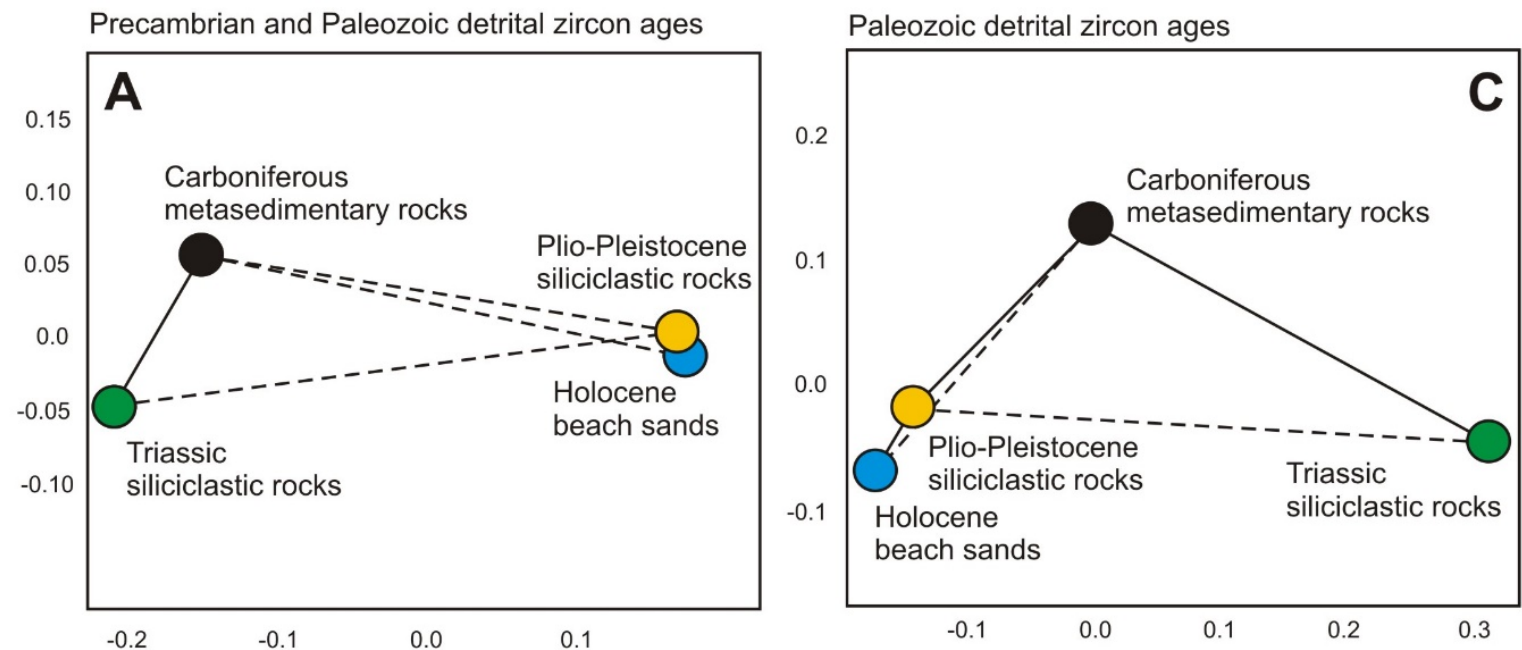

Precambrian detrital zircon ages

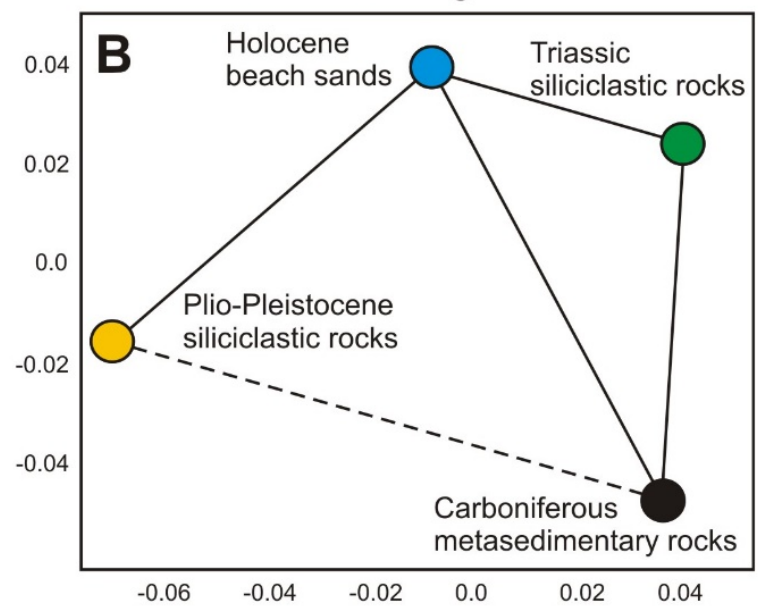

All detrital and igneous zircon ages

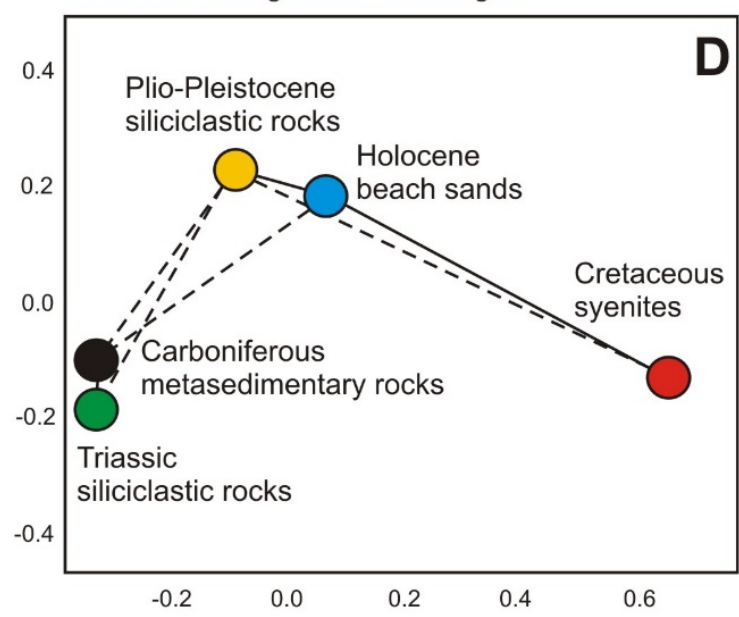

Figure 5. Multidimensional scaling (MDS) diagrams with U-Pb detrital zircon ages of the Carboniferous (Mira Formation, South Portuguese Zone), Triassic (Silves Group, Alentejo Basin), and Pliocene-Pleistocene (Alvalade Basin) siliciclastic rocks, as well as Holocene beach sands from the Sines region. (A) Precambrian and Paleozoic detrital zircon ages. (B) Precambrian detrital zircon ages. (C) Paleozoic detrital zircon ages. (D) All detrital zircon ages together with the magmatic zircon ages from the Sines pluton (U-Pb data compiled from $[16,28,29,34,39,40])$.

\section{Provenance of the Sines Holocene Beach Sand}

\subsection{Distal and Local Provenance}

The analysis of the compiled $\mathrm{U}-\mathrm{Pb}$ data showed a degree of similarity between the detrital zircon populations of Carboniferous and Triassic sedimentary rocks, which were both dominated by Precambrian grains (mostly Neoproterozoic and Paleoproterozoic), suggesting that those found in the Triassic samples were recycled from Carboniferous rocks.

Previous studies [29,39] demonstrated that the Carboniferous Mira Formation probably resulted from the erosion of the Ediacaran to Devonian metasedimentary and metaigneous rocks of the southwest Iberia basement. In turn, Carboniferous turbidites appeared to be the dominant source of Triassic Alentejo sandstones and conglomerates [34,35,40]. Thus, most of the Precambrian and Paleozoic detrital zircon grains passed through Carboniferous metasedimentary rocks before reaching the Triassic Basin. Carboniferous metasedimentary rocks are the oldest ISR exposed today in the provenance areas draining into the Sines coastline (Figure 6). 
A Holocene sedimentation
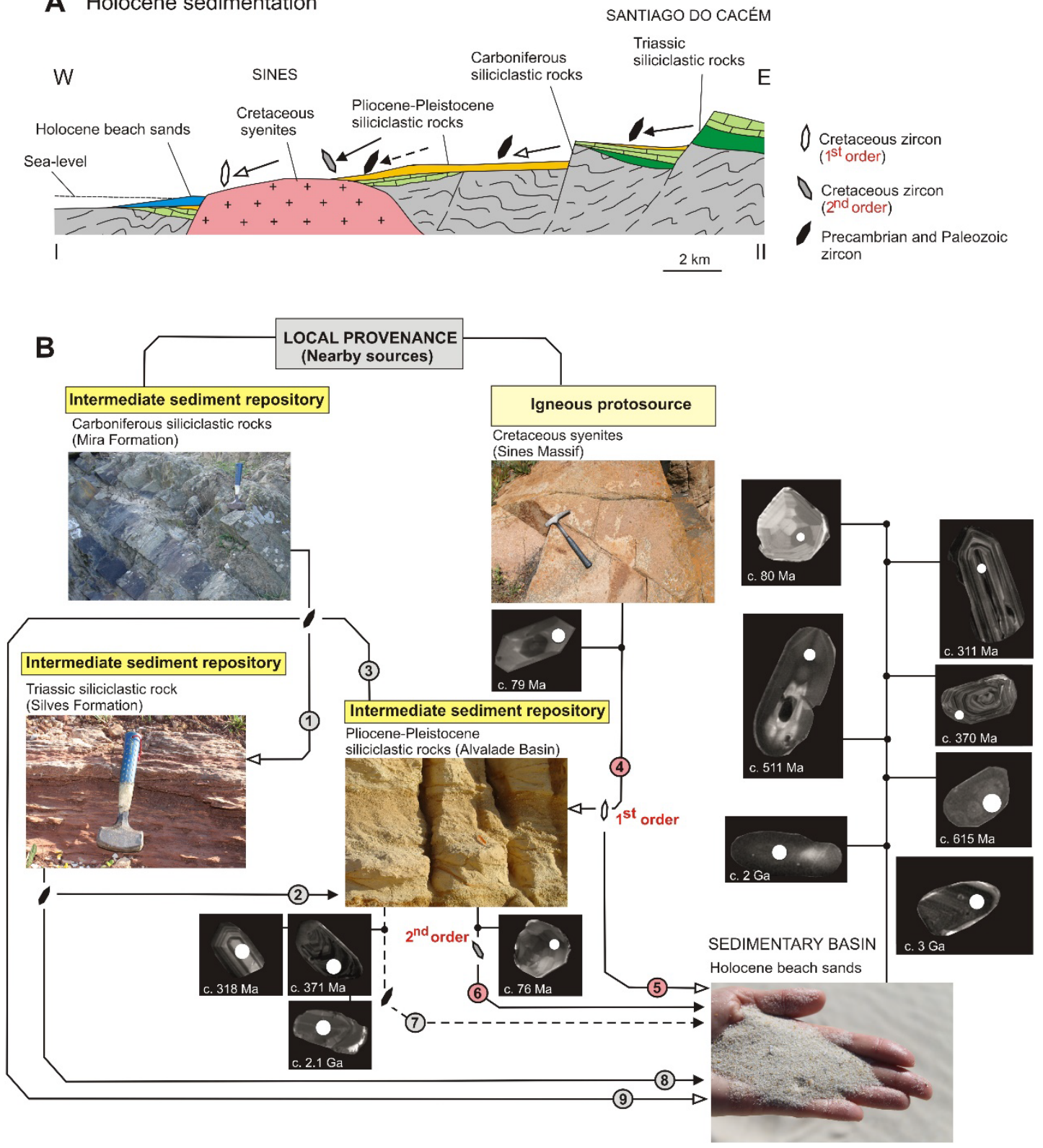

Figure 6. (A) Schematic geological cross-section I-II (see location and legend in Figure 2) showing the provenance of the Sines Holocene beach sands. (B) Flow diagram illustrating the different zircon provenance ages and the possible delivery pathways into the Sines Holocene beach sands, with cathodoluminescence images of representative zircon grains from the Cretaceous syenite, Pliocene-Pleistocene siliciclastic rocks, and Holocene beach sands [16,28,30].

Figure 6 illustrates the flow of Precambrian and Paleozoic detrital zircon grains derived from the erosion of the (oldest) Carboniferous ISR and then transported and deposited in the Triassic Alentejo Basin (Figure 6B-1). Precambrian and Paleozoic detrital zircon grains found in the Pliocene-Pleistocene siliciclastic rocks may have mostly represented recycled material from the Carboniferous (Figure 6B-2) and Triassic (Figure 6B-3) ISRs, as indicated by the CAD curves, which are nearly coincident (Figure 3B). Some differences stand out in the MDS graphs, which compare the Precambrian and Paleozoic detrital zircon age groups individually (Figure 5B,C). The comparison between the Precambrian zircon age groups of the Carboniferous, Triassic, and Pliocene-Pleistocene ISRs with Holocene beach sand showed that they were not significantly different (Table 2). However, the same cannot be said for the Paleozoic age groups. The Triassic ISR detrital zircon population was different 
from the others, and the Carboniferous ISR was significantly different from the Holocene beach, which presented Permo-Carboniferous grains (Table 1).

While local provenance is the most likely possibility, distal sources may also provide a contribution to the Sines beach sand. In the Sines-Santiago do Cacém region, outcrops of Precambrian rocks are unknown, but there are Neoproterozoic and Paleoproterozoic age groups present in Sines Holocene beach sands. The oldest rocks found in the southwest Iberia basement are Ediacaran metasedimentary rocks, which outcrop at least $70 \mathrm{~km}$ inland to the east. These Ediacaran metasedimentary rocks represent an ISR related to the erosion of a Neoproterozoic (Cadomian) magmatic arc built on the Paleoproterozoic basement $[44,45]$, which is not recognized in Iberia. Ediacaran siliciclastic rocks include two main groups of detrital zircon grains-the Neoproterozoic and Paleoproterozoic agesand a characteristic gap of the Mesoproterozoic age [46], which coincide with the detrital zircon age groups of Holocene sands. Thus, we can also presume that Holocene beach sand was transported over long distances from remote sources located northeast of Sines. Precambrian detrital zircon may have been transported through the Sado River (located $65 \mathrm{~km}$ north of Cape Sines, Figure 2A), reaching the Atlantic coast (Sado Ebb-tidal delta) and then being distributed in the Holocene beach due to the southward littoral drift of sediment [47]. Alternatively, the lack of 1.6-1 Ga detrital zircon grains in Holocene beach sand may have been due to a sampling error; thus, further geochronological data are required. The lack of Mesoproterozoic grains is not a decisive factor in the interpretation of the provenance of Sines Holocene sand, because the K-S test results (Table 2) and MDS graphs (Figure 5) indicated that they were not significantly different from the detrital zircon population of Pliocene-Pleistocene siliciclastic rocks.

\subsection{Recycling of a Protosource: First- and Second-Order Zircon}

In this section, the role of the recycling of a Cretaceous igneous protosource (Sines Syenite, Figure 6) in a Cenozoic sedimentary system is discussed. Before the beginning of the input of Cretaceous zircon from this new contributor, the available sources were exclusively ISRs. This new age component of local provenance started to mix with the recycling of older ISRs during Pliocene-Pleistocene sedimentation. Cretaceous zircon grains were recycled from Sines plutonic rocks and were responsible for a decrease in the relative representation of Precambrian and Paleozoic age groups derived from the older ISRs, as suggested by the KDE plots (Figure 3A). The zircon derived directly from the first-cycle erosion of the protosource found in Pliocene-Pleistocene siliciclastic rocks may be classified as first-order Cretaceous zircon (Figure 6B-4).

In the Holocene, Sines syenites remain as a protosource for Holocene beach sands, thus providing first-order Cretaceous zircon to the sedimentary basin (Figure 6B-5). The PliocenePleistocene siliciclastic rocks forming the coastal plain and the sea cliffs (mainly to the north of Cape Sines) represent a possible source of Holocene beach sands, as evidenced by the remarkable similarities between the detrital zircon distributions of both in the KDE, CAD, and MDS graphs (Figures 3-5). These results allow us to infer that the Pliocene-Pleistocene sequence constituted an ISR for the Holocene sedimentary basin. In this case, the ISR, made of recycled material from Carboniferous and Triassic ISRs (Precambrian and Paleozoic detrital zircon grains), also provided Cretaceous zircon derived directly from the Sines pluton (first-cycle erosion) (Figure 6B-7). Zircon grains from the Sines syenites that passed through the Pliocene-Pleistocene ISR and were then transported and deposited in the Holocene basin may be second-order Cretaceous zircon (Figure 6B-6). Besides this, Precambrian and Paleozoic detrital zircon grains were also probably incorporated in the Holocene deposits directly from Carboniferous and Triassic ISRs (Figure 6B-8,9). The development of a series of small-scale alluvial fans related to Pliocene-Pleistocene sources at the base of the sea cliff supports this interpretation. However, it may be that the Holocene beach sand was also derived from a mixture of Cretaceous syenite (first-cycle erosion) and Carboniferous bedrock (ISR) found in the region [16]. 
The challenge to differentiate sediment recycling from the first-cycle erosion of bedrock, which was addressed in this study, is common to other source-to-sink investigations involving modern sediment. A recent provenance study on the detrital zircon age distributions of Paleogene North American Cordilleran strata [48] is a convincing example in this respect.

Author Contributions: Conceptualization, M.F.P.; data curation, C.G.; investigation, C.G.; methodology, M.F.P.; writing-original draft, M.F.P. and C.G. Both authors have read and agreed to the published version of the manuscript.

Funding: This work was supported through the Portuguese Foundation for Science and Technology (FCT) project UIDB/04683/2020, Instituto de Ciências da Terra.

Institutional Review Board Statement: Not applicable.

Informed Consent Statement: Not applicable.

Data Availability Statement: Not applicable.

Acknowledgments: We thank the comments of two anonymous reviewers that have contributed decisively to improve the content of this manuscript.

Conflicts of Interest: The authors declare no conflict of interest.

\section{References}

1. Vavra, G. On the kinematics of zircon growth and its petrogenetic significance: A cathodoluminescence study. Contrib. Miner. Petrol. 1990, 106, 90-99. [CrossRef]

2. Hanchar, J.; Miller, C. Zircon zonation patterns as revealed by cathodoluminescence and backscattered electron images: Implications for interpretation of complex crustal histories. Chem. Geol. 1993, 110, 1-13. [CrossRef]

3. Vavra, G.; Gebauer, D.; Schmid, R.; Compston, W. Multiple zircon growth and recrystallization during polyphase Late Carboniferous to Triassic metamorphism in granulites of the Ivrea Zone (Southern Alps): An ion microprobe (SHRIMP) study. Contrib. Mineral. Petrol. 1996, 122, 337-358. [CrossRef]

4. Corfu, F.; Hanchar, J.M.; Hoskin, P.W.; Kinny, P. Atlas of Zircon Textures. Rev. Miner. Geochem. 2003, 53, 469-500. [CrossRef]

5. Charlier, B.L.A.; Wilson, C.J.N.; Lowenstern, J.B.; Blake, S.; Van Calsteren, P.W.; Davidson, J.P. Magma Generation at a Large, Hyperactive Silicic Volcano (Taupo, New Zealand) Revealed by U-Th and U-Pb Systematics in Zircons. J. Petrol. 2004, 46, 3-32. [CrossRef]

6. Miller, J.S.; Matzel, J.E.; Miller, C.F.; Burgess, S.D.; Miller, R.B. Zircon growth and recycling during the assembly of large, composite arc plutons. J. Volcanol. Geotherm. Res. 2007, 167, 282-299. [CrossRef]

7. Fedo, C.M.; Sircombe, K.N.; Rainbird, R.H. Detrital Zircon Analysis of the Sedimentary Record. Rev. Miner. Geochem. 2003, 53, 277-303. [CrossRef]

8. Gehrels, G.E.; Blakey, R.; Karlstrom, K.E.; Timmons, J.M.; Dickinson, B.; Pecha, M. Detrital zircon U-Pb geochronology of Paleozoic strata in the Grand Canyon, Arizona. Lithosphere 2011, 3, 183-200. [CrossRef]

9. Sircombe, K.; Hazelton, M.L. Comparison of detrital zircon age distributions by kernel functional estimation. Sediment. Geol. 2004, 171, 91-111. [CrossRef]

10. Dickinson, W.R. Provenance and sediment dispersal in relation to paleotectonics and paleogeography of sedimentary basins. In New Perspectives in Basin Analysis; Kleinspehn, K.L., Paola, C., Eds.; Springer: New York, NY, USA, 1988 ; pp. 3-25.

11. Weltje, G.J.; von Eynatten, H. Quantitative provenance analysis of sediments: Review and outlook. Sediment. Geol. 2004, 171, 1-11. [CrossRef]

12. Ireland, T.R.; Bradshaw, J.D.; Muir, R.; Weaver, S.; Adams, C. Zircon age distributions in granites, greywackes, and gneisses from the southwest Pacific-Gondwana region. In Abstracts of the Eighth International Conference on Geochronology, Cosmochronology, and Isotope Geology; U.S. Geological Survey: Reston, VA, USA, 1994; Volume 1107, p. 151.

13. Sircombe, K.N. Tracing provenance through the isotope ages of littoral and sedimentary detrital zircon, eastern Australia. Sediment. Geol. 1999, 124, 47-67. [CrossRef]

14. Morton, A.; Fanning, M.; Milner, P. Provenance characteristics of Scandinavian basement terrains: Constraints from detrital zircon ages in modern river sediments. Sediment. Geol. 2008, 210, 61-85. [CrossRef]

15. Thomas, W.A. Detrital-zircon geochronology and sedimentary provenance. Lithosphere 2011, 3, 304-308. [CrossRef]

16. Pereira, M.F.; Albardeiro, L.; Gama, C.; Chichorro, M.; Hofmann, M.; Linnemann, U. Provenance of Holocene beach sand in the Western Iberian margin: The use of the Kolmogorov-Smirnov test for the deciphering of sediment recycling in a modern coastal system. Sedimentology 2016, 63, 1149-1167. [CrossRef]

17. Pell, S.D.; Williams, I.S.; Chivas, A.R. The use of protolith zircon-age fingerprints in determining the protosource areas for some Australian dune sands. Sediment. Geol. 1997, 109, 233-260. [CrossRef] 
18. Williams, I.S.; Chappell, B.W.; Chen, Y.D.; Crook, K.A.W. Inherited and detrital zircons-Vital clues to the granite protoliths and early igneous history of southeastern Australia. Trans. R. Soc. Edinb. Earth Sci. 1992, 83, 503.

19. Sircombe, K.N.; Freeman, M.J. Provenance of detrital zircons on the Western Australian coastline: Implications for the geologic history of the Perth basin and denudation of the Yilgan craton. Geology 1999, 27, 879-882. [CrossRef]

20. DeGraaff-Surpless, K.; Mahoney, J.B.; Wooden, J.L.; McWilliams, M.O. Lithofacies control in detrital zircon provenance studies: Insights from the Cretaceous Methow basin, southern Canadian Cordillera. GSA Bull. 2003, 115, 899-915. [CrossRef]

21. Barbeau, D.L.; Davis, J.T.; Murray, K.E.; Valencia, V.; Gehrels, G.E.; Zahid, K.M.; Gombosi, D.J. Detrital-zircon geochronology of the metasedimentary rocks of north-western Graham Land. Antarct. Sci. 2009, 22, 65. [CrossRef]

22. Vermeesch, P. On the visualization of detrital age distributions. Chem. Geol. 2013, 341, 140-146. [CrossRef]

23. Vermeesch, P.; Garzanti, E. Making geological sense of 'Big Data' in sedimentary provenance analysis. Chem. Geol. 2015, 409, 20-27. [CrossRef]

24. Vermeesch, P. Dissimilarity measures in detrital geochronology. Earth-Sci. Rev. 2018, 178, 310-321. [CrossRef]

25. Wissink, G.K.; Wilkinson, B.H.; Hoke, G.D. Pairwise sample comparisons and multidimensional scaling of detrital zircon ages with examples from the North American platform, basin, and passive margin settings. Lithosphere 2018, 10, 478-491. [CrossRef]

26. Reis, A.H.; Gama, C. Sand size versus beachface slope-An explanation based on the Constructal Law. Geomorphology 2010, 114, 276-283. [CrossRef]

27. Gama, C. Dinâmica de Sistemas Sedimentares do Litoral Ocidental Português a Sul do Cabo Espichel. Ph.D. Thesis, Universidade de Évora, Évora, Portugal. (unpublished).

28. Albardeiro, L.; Pereira, M.F.; Gama, C.; Chichorro, M.; Hoffman, M.; Linnemann, U. Provenance study of Pliocene-Plestocene sands based on ancient detrital zircons (Alvalade Basin, SW Iberian Atlantic coast). Sediment. Geol. 2014, 307, 47-58. [CrossRef]

29. Pereira, M.F.; Ribeiro, C.; Vilallonga, F.; Chichorro, M.; Drost, K.; Silva, J.B.; Albardeiro, L.; Hofmann, M.; Linnemann, U. Variability over time in the sources of South Portuguese Zone turbidites: Evidence of denudation of different crustal blocks during the assembly of Pangea. Int. J. Earth Sci. 2014, 103, 1453-1470. [CrossRef]

30. Albardeiro, L. Aplicação da Geocronologia U-Pb em Zircão a Areias e Rochas do Substrato do Litoral do Sudoeste de Portugal: Implicações para a Proveniência, Dinâmica Sedimentar e História Geológica da Região. Ph.D. Thesis, Universidade de Évora, IIFA, Évora, Portugal, 2015; p. 328, (unpublished).

31. Oliveira, J.T.; Pereira, E.; Ramalho, M.; Antunes, M.T.; Monteiro, J.H. Carta Geológica de Portugal, Notícia explicativa da Folha Sul, Scale 1/500 000; Serviços Geológicos de Portugal: Lisboa, Portugal, 1992.

32. Inverno, C.M.C.; Manuppella, G.; Zbyszewski, G.; Pais, J.; Ribeiro, M.L. Carta Geológica de Portugal, Notícia explicativa da Folha 42-C (1:50000), Santiago do Cacém; Serviços Geológicos de Portugal: Lisboa, Portugal, 1993.

33. Pereira, M.F.; Gama, C.; Da Silva, D.; Fuenlabrada, J.M.; Silva, J.B.; Medina, J.M. Isotope geochemistry evidence for Laurussiantype sources of South Portuguese Zone Carboniferous turbidites (Variscan Orogeny). Geol. Soc. Lond. Spec. Publ. 2020, 503, 619-642. [CrossRef]

34. Pereira, M.F.; Ribeiro, C.; Gama, C.; Drost, K.; Chichorro, M.; Vilallonga, F.; Hofmann, M.; Linnemann, U. Provenance of upper Triassic sandstone, southwest Iberia (Alentejo and Algarve basins): Tracing variability in the sources. Int. J. Earth Sci. 2016, 106, 43-57. [CrossRef]

35. Pereira, M.F.; Gama, C. Detrital provenance of the Upper Triassic siliciclastic rocks from southwest Iberia: A review. J. Iber. Geol. 2017, 43, 379-393. [CrossRef]

36. Verati, C.; Rapaille, C.; Féraud, G.; Marzoli, A.; Bertrand, H.; Youbi, N. 40Ar/39Ar ages and duration of the Central Atlantic Magmatic Province volcanism in Morocco and Portugal and its relation to the Triassic-Jurassic boundary. Palaeogeogr. Palaeoclim. Palaeoecol. 2007, 244, 308-325. [CrossRef]

37. Miranda, R.; Valadares, V.; Terrinha, P.; Mata, J.; Azevedo, M.; Gaspar, M.; Kulberg, J.; Ribeiro, C. Age constrains on the Late Cretaceous alkaline magmatism on the West Iberian Margin. Cretac. Res. 2009, 30, 575-586. [CrossRef]

38. Pais, J.; Cunha, P.P.; Pereira, D.I.; Legoinha, P.; Dias, R.; Moura, D.; Da Silveira, A.B.; Rocha, R.B.; Delgado, J.G. The Paleogene and Neogene of Western Iberia (Portugal): A Cenozoic Record in the European Atlantic Domain; Springer: Berlin, Germany, 2011; pp. 1-138. [CrossRef]

39. Rodrigues, B.; Chew, D.; Jorge, R.; Fernandes, P.; Veiga-Pires, C.; Oliveira, J.T. Detrital zircon geochronology of the Carboniferous Baixo Alentejo Flysch Group (South Portugal); Constraints on the provenance and geodynamic evolution of the South Portuguese Zone. J. Geol. Soc. 2015, 172, 294-308. [CrossRef]

40. Dinis, P.A.; Fernandes, P.; Jorge, R.C.G.S.; Rodrigues, B.; Chew, D.M.; Tassinari, C.G. The transition from Pangea amalgamation to fragmentation: Constraints from detrital zircon geochronology on West Iberia paleogeography and sediment sources. Sediment. Geol. 2018, 375, 172-187. [CrossRef]

41. Frei, D.; Gerdes, A. Precise and accurate in situ U-Pb dating of zircon with high sample throughput by automated LA-SF-ICP-MS. Chem. Geol. 2009, 261, 261-270. [CrossRef]

42. Vermeesch, P. Multi-sample comparison of detrital age distributions. Chem. Geol. 2012, 341, 190-194. [CrossRef]

43. Guynn, J.; Gehrels, G. Comparison of Detrital Zircon Age Distributions Using the K-S Test. Arizona LaserChron Center. 2010. Available online: https:/ / laserchron.org/ (accessed on 15 October 2020). 
44. El Houicha, M.; Pereira, M.F.; Jouhari, A.; Gama, C.; Ennih, N.; Fekkak, A.; Ezzouhairi, H.; El Attari, A.; Silva, J.B. Recycling of the Proterozoic crystalline basement in the Coastal Block (Moroccan Meseta): New insights for understanding the geodynamic evolution of the northern peri-Gondwanan realm. Precambrian Res. 2018, 306, 129-154. [CrossRef]

45. Pereira, M.F.; El Houicha, M.; Chichorro, M.; Armstrong, R.; Jouhari, A.; El Attari, A.; Ennih, N.; Silva, J. Evidence of a Paleoproterozoic basement in the Moroccan Variscan Belt (Rehamna Massif, Western Meseta). Precambrian Res. 2015, 268 , 61-73. [CrossRef]

46. Pereira, M.F.; Chichorro, M.; Williams, I.S.; Silva, J.B. Zircon U-Pb geochronology of paragneisses and biotite granites from the SW Iberian Massif (Portugal): Evidence for a paleogeographic link between the Ossa-Morena Ediacaran basins and the West African craton. In The Boundaries of the West African Craton; Liégeois, J.P., Nasser, E., Eds.; Geological Society of London: London, UK, 2008; pp. 385-408.

47. Du, X.; Gama, C.; Liu, J.T.; Baptista, P. Sediment Sources and Transport Pathway Identification Based on Grain-Size Distributions on the SW Coast of Portugal. Terr. Atmos. Ocean. Sci. 2015, 26, 397. [CrossRef]

48. Schwartz, T.; Schwartz, R.; Weislogel, A. Orogenic Recycling of Detrital Zircons Characterizes Age Distributions of North American Cordilleran Strata. Tectonics 2019, 38, 4320-4334. [CrossRef] 